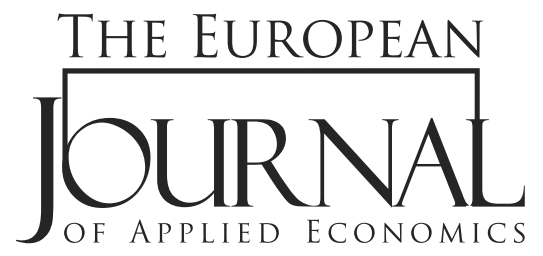

EJAE 2019, 16(1): 41-58

ISSN 2406-2588

UDK: $330.322: 339.722(4)$

336.76

DOI: 10.5937/EJAE15-19652

Original paper/Originalni naučni rad

\title{
GOLD IN INVESTMENT PORTFOLIO FROM PERSPECTIVE OF EUROPEAN INVESTOR
}

\author{
Tijana Šoja \\ Central Bank of Bosnia and Herzegovina, \\ Sarajevo, Bosnia and Herzegovina
}

\begin{abstract}
:
Gold is a unique asset, highly liquid, but scarce and limited. It is a luxury good and can be considered an investment opportunity. Gold is an asset which does not carry counterparty risk - there is no associated credit risk. Due to these characteristics, gold represents a significant asset, and has a fundamental role in investment portfolios. These circumstances increase the interests of investors to include gold in investment portfolios, especially during times of financial crisis. If an investor decides to include gold in investment portfolio, it is necessary to evaluate the portion of gold in the portfolio considering risk aspect, return and diversification. In this research, a hypothesis was tested and confirmed that gold offers good diversification for the investment portfolio, which implies that gold is a desirable asset in the investment portfolio.

This research is focused on developing an optimal portfolio that combines the Eurozone bond index with the investment grade rating from 1 to 10 years (EG05), the stock index Euro Stoxx50 and gold using the Markowitz methodology. The result showed that optimal portfolio should include gold with a share between $1 \%$ to $9 \%$, depending on the risk that the investor is willing to accept.
\end{abstract}

\section{Article info:}

Received: November 23, 2018

Correction: December 28, 2018

Accepted: January 31, 2019

\section{Keywords:}

gold, investment, portfolio, crisis.

\section{INTRODUCTION}

Throughout history, gold has always had a noticeable reputation and different characteristics: it held the role of a global currency, it was sometimes seen as goods, sometimes as a financial asset and, of course, as jewellery. During the rapid development of the global financial market in the 1980's and 1990 's, gold became an increasingly attractive investment. Moreover, the last financial crisis in 2007/8 and the debt crisis in Europe in 2010 increased the interest of investors for gold. Investors want gold in their portfolios for many reasons. Some investors invest in gold in order to realise profit from the 
growth of the price of gold and take into account the limited supply of gold that can affect the price increase. Other gold investors consider it a strategic asset and a long-term investment because of the specific characteristics of this investment asset.

Financial crises, such as the global crisis 2007/8, increase the demand for safe assets like gold, as it is perceived as an asset that preserves its value and provides a high level of security in times of crisis. In addition, gold plays an important role in improving portfolio performance, portfolio diversification, and could reduce overall portfolio risk. Due to these characteristics, it is argued that gold is a desirable instrument in financial portfolios.

Previous research claim that asset class commodity could be the answer to many problems in investment activity today, and investment problems that the investment world faces. Because of the low correlation between commodity and bonds, equities and inflation, investment in commodity, such as gold, could be an valuable component in investment portfolios (Idzorek, 2006; Conover et al., 2010). Gold is also considered an asset which can offer inflation hedge due to its low or negative correlation with inflation and currency devaluation. During times of inflationary pressures, the price of gold generally increases in order to balance inflationary consequences and hold purchasing power (Erb \& Harvey, 2013).

Academic studies have also shown that gold is an attractive investment, especially as an investment vehicle to diversify portfolios. Conover et al., (2009) but also Daskalaki \& Skiadopoulos (2011) have shown that investment portfolios which include precious metals, like gold or silver, demonstrate a better rate of performance than portfolios without them.

Obviously, there is evidence that gold, as a financial asset, has an important role in diversifying investment portfolios and can improve their performance. In such circumstances, it is useful to research the role of gold in European portfolios during and after the financial crisis of 2007/8. It was found that there is a gap in research, which examined the optimal share of gold in investment portfolios during the pre-crisis and post-crisis period, but also research papers that mainly focused on European investors.

The aim of this study is to explore the optimal share of gold in investment portfolios from the perspective of a European investor. The optimal share of gold in the investment portfolio is being examined from a European investor perspective that invests in portfolios which contain three instruments: Eurozone government bonds, shares of European companies, and gold. Previous research has shown that a low correlation between these assets could improve portfolio performance, and we will therefore explore what an optimal share of gold in such an investment portfolio would be.

Bearing this in mind, the hypothesis that gold offers a good diversification for investment portfolios, thus implying that gold is a desirable asset in portfolios, will be examined in this research. The starting point is the assumption that the investor does not have a high-risk appetite, and prefers a lower risk portfolio. The empirical research is focused on the period from January 2000 to December 2017. Monthly data were used for the analyzed instruments, as follows:

- The EG05 index, which includes investment grade government bond maturity from 1 to 10 years,

- The Euro index Stoxx50, representing the top 50 shares of the best-performing companies from eleven Eurozone countries, and

- The price of gold expressed in dollars.

The desired share of gold in investment portfolios is estimated throughout two periods: from January 2000 to December 2017, and during the global crisis from January 2007 to December 2017. For portfolio construction and examining the optimal share of gold in investment portfolios, the modern portfolio theory proposed by Markowitz will be used.

This research is divided into several thematic units: literature review, research methodology, research findings, analysis, and concluding remarks. 


\section{LITERATURE REVIEW}

The role of gold in investment portfolios and the need to be included in investment portfolios, are interesting and current topics. According to Hillier et al. (2006), the existing literature that treats the role of gold in portfolios and the role of gold as an investment, can generally be classified into several areas, thus, gold is analyzed as a form of hedging, as an instrument of portfolio diversification, its connection with macroeconomic factors and gold production and its characteristics. From the perspective of this research, our focus will be on the role of gold in investment portfolios, so gold will be observed as a financial asset.

Usually, investors diversify portfolios through two key assets, i.e. stocks and bonds (Idzorek, 2006). However, with increased globalization, research has shown that the correlation among primary assets has observed a steady growth (Idzorek, 2005; Johnson \& Soenen, 1997). As a result,, investors did not enjoy a high degree of portfolio diversification and their investments were not protected enough from the financial market turbulence (Ratner \& Klein, 2008; Bernhart et al., 2011).

Economic and political crises have influenced investors to include assets with a lower correlation with shares and bonds in portfolios, in order to diversify them. In this context, the idea of including new assets, such as gold, in portfolios with the aim of diversification, is desirable.

Numerous analysts consider gold a good alternative to diversification, due to its low correlation with traditional assets (Idzorek, 2006; Conover et al., 2010). Gold is often perceived as a "safe haven" and as an asset that protects wealth and value in times of inflation, resulting from a low correlation of gold with market trends (Clapperton, 2010; Conover et al., 2009).

During periods of global uncertainty, many investors choose to invest in gold because it is regarded as a safe investment. In addition to this, the rise in the price of gold, which has been present since 1999 through 2012, has led to a $15.4 \%$ annual return on gold investment. This is a far greater return than offered by shares in the U.S. (return of 1.5\%) and bonds (return of 6.4\%) over the same period (Fernando, 2017).

Researchers have a different stance towards gold as an investment option. Some researchers highlight negative attitudes to gold in investment portfolios, while some have a positive view about gold and its role in portfolios. Investors, such as Warren Buffett, believe that gold is a non-productive asset that increases fears among its investors. He considers that the rise in gold prices from 2010 to 2012 was a "balloon", and compares it to the 17th-century Tulipomania, the dot-com crisis in the 1990's and the latest crisis of 2008. Numerous sceptics of gold generally support Buffett's claims (Fernando, 2017).

The World Gold Council-or WGC (2018) highlights that gold is a highly liquid, scarce asset and is no one's liability. Moreover, gold is a luxury good, but also an investment. Because of these characteristics, gold can have a very important, even fundamental, role in investment portfolios. By adding gold to investment portfolios, investors can increase diversification but also enhance risk-adjusted returns. The WGC (2018) found that US dollar institutional investors, by adding $2 \%, 5 \%$ or $10 \%$ in gold, have increased returns and reduced volatility. Their analysis also showed that, for most US dollar investors, holdings between $2 \%$ to $10 \%$ of gold can improve portfolio performance.

The majority of researchers and analysts point out that gold is an attractive asset, and represents a good basis for portfolio diversification. Researchers have shown that portfolios containing precious metals, such as gold and platinum, have recorded significantly better performances than standard stock portfolios without gold (Conover et al., 2009; Daskalaki \& Skiadopoulos, 2011; Hillier et al., 2006). Nevertheless, advocates of gold-inclusive portfolios suggest that gold can minimize the standard deviation of the total portfolio risk, reduce volatility, and boost returns (Merk Investments, 2012).

Gold can be the valuable asset for diversification - even a small share of gold in the portfolio, between $1 \%$ and 3\%, can significantly reduce the overall portfolio risk (Michaud et al., 2011). Research 
conducted during the 1980s', such as Sherman (1982), suggest that the 5\% share of gold in the stock portfolio resulted in lower risk and higher returns. Lucey et al. (2006) examined the structure of portfolios, investors, and their focus on finding optimal portfolios, and demonstrated that the optimal portfolio has $6 \%$ to $25 \%$ of gold, depending on the period of investment.

Numerous evidence suggest that gold can serve as a safe haven and an asset that provides a high degree of protection against inflation and currency depreciation, as observed over a long period of time (Baur \& Lucey, 2010; Conover et al., 2009; Ghosh et al., 2004; Capie et al., 2005; Joy, 2011). Similarly, Pullen et al, (2014) demonstrate and confirm that gold represents good protection in periods of financial disasters.

Baur and Lucey (2010) studied constant and time-varying relations between the U.S., the U.K., and German stock and bond returns and gold returns in order to explore gold as a hedge and safe haven. They found that gold, on average, is a safe haven in extreme stock market conditions, but did not found that gold is a safe haven for bonds at any analyzed market.

As we can see from previous research, there is a lot of evidence that gold represents a good basis for diversification portfolios. Furthermore, there are many papers on U.S. portfolios and role of gold, but not those on European investing in EUR financial instruments (bonds and shares). Additionally, there is lack of research on the optimal role of gold in EUR portfolios during and after crisis 2007/8. Considering all the abovementioned, this research will show that gold has a significant role in EUR investment portfolios, and can be used for diversification.

\section{METHODOLOGY}

The role and share of gold in portfolios was analyzed for the period from January 2000 to December 2017. The analysis includes the following instruments: Eurozone government bond index (EG05), Euro area stocks (Euro Stoxx50), and gold. All data is on a monthly basis, i.e., the analysis includes the value of each instrument at the end of the month. Firstly, a monthly return for each instrument is calculated using the following expression (Bodie, et al 2014):

$$
R_{t}=\ln \left(\frac{p_{t}}{p_{t-1}}\right)
$$

$R t$ represents a return, $\ln$ is the natural logarithm, $p_{t}$ is the value in the current period and $p_{t-1}$ is the value in the previous period. Complete portfolio optimization was carried out based on the data on the monthly return of analyzed instruments.

The average of return, necessary for the analysis, is calculated as follows:

$$
x=\frac{x_{1}+\ldots x_{n}}{n}
$$

The standard deviation as a measure of the dispersion of the return, i.e., the deviation of the individual return from the middle value, was calculated using the following expression (Bodie, et al 2014):

$$
\sigma=\sqrt{\frac{1}{n}} \sum_{i=1}^{n}\left(x_{i}-\bar{x}\right)^{2}
$$

For calculating the $\mathrm{VaR}$ it is important to consider the observation period, as well as the confidence interval. Parameter $\mathrm{VaR}$ is known as the method of variance and covariance, and the formula for calculating parametric $V a R$ is the following (Bodie, et al 2014): 


$$
\operatorname{VaR}_{x, a}=-z_{a} \cdot \sigma \cdot S
$$

In the above formula, $z_{a}$ represent the quantile order $\alpha$ of standardized random variables, $S$ is the value of the position being calculated. $V a R$ was calculated with a confidence interval of $95 \%$. The optimal portfolio is determined using the Markowitz method, or a modern portfolio theory. This theory involves the calculation of correlation and covariation among the instruments included in the portfolio, as well as the calculation of the expected return and portfolio risk.

The expected return of the portfolio is calculated using the following expression (Levišauskait, 2010):

$$
E_{r(p)}=\sum_{i=1}^{n} w_{1} \cdot E_{i(r)}=w_{1} \cdot E_{1(r)}+w_{2} \cdot E_{2(r)}+\ldots+w_{n} \cdot E_{n(r)}
$$

where the following applies:

$E_{r(p)}$ - Expected portfolios return

$E_{i(r)}$ - The expected rate of return on a financial instrument

$w_{i}$ - The share of the value of the portfolio that is invested in financial instrument $\mathrm{i}$

$\mathrm{n}$ - Number of financial instruments in the portfolio

In order to deploy an efficient portfolio, it is necessary to calculate the covariance that measures how two variables move together - whether to move in the same direction, so they have a positive covariance, or move in a different, opposite direction, so they have a negative covariance. Covariance is calculated as follows (Bodie, et al 2014):

$$
\text { Covariance }(A, B)=\frac{\sum\left(R_{A}-\overline{R_{A}}\right)\left(R_{B}-\overline{R_{B}}\right)}{N}
$$

where the following applies:

$\mathrm{R}_{\mathrm{A}}$ - Return of instrument A (the same holds for instrument $B$ )

$\overline{R_{A}}-$ Average return for instrument $\mathrm{A}$ (the same hold for instrument $\mathrm{B}$ )

For the next step, it is necessary to calculate the correlation between the instruments in order to determine the strength of the relationship between the instruments in a portfolio. The correlation should be used in conjunction with the covariance, and is represented as follow (Bodie, et al 2014):

$$
\text { Correlation }=p=\frac{\operatorname{Cov}(A, B)}{\sigma_{A} \sigma_{B}}
$$

where the following applies:

Cov $(A, B)$ - Covariance between instrument $A$ and instrument $B$

$\sigma_{A} \sigma_{B}$ - Standard deviation of A and B

The portfolio risk that consists of three securities (A, B and C) can be calculated as follows (Levišauskait, 2010):

$$
\sigma_{P}=\left(w_{A}^{2} \cdot \sigma_{A}^{2}+w_{B}^{2} \cdot \sigma_{B}^{2}+w_{C}^{2} \cdot \sigma_{C}^{2}+2 w_{A} w_{B} w_{A B}+2 w_{A} w_{C} w_{A C}+2 w_{B} w_{C} w_{B C}\right)^{1 / 2}
$$


where the following applies:

$\mathrm{w}_{\mathrm{A}}, \mathrm{W}_{\mathrm{B}}, \mathrm{w}_{\mathrm{C}}$ - Share of initially invested values of financial instruments $\mathrm{A}, \mathrm{B}$ and $\mathrm{C}\left(w_{A+} w_{B}+w_{C}=1\right)$

$\sigma_{A}, \sigma_{B}, \sigma_{C}$ - Standard deviation of financial instruments

\section{RESULTS OF RESEARCH}

This research has observed and analyzed during the period from January 2000 to December 2017, and the period from January 2007 to December 2017. All calculations are made for these two periods in Excel.

In the first step, all data are analyzed and demonstrated using descriptive statistics. Var, as an initial measure of risk, was calculated. The results are shown in Table 1:

\begin{tabular}{cccc}
\hline & EG05 & EURO STOXX50 & Gold \\
\hline Mean & $0.36 \%$ & $-0.02 \%$ & $0.82 \%$ \\
\hline StDev & $0.81 \%$ & $5.25 \%$ & $4.87 \%$ \\
\hline Freq<0 & $31.94 \%$ & $46.30 \%$ & $44.91 \%$ \\
\hline Parametric $\mathrm{VaR}$ & $-0.97 \%$ & $-8.66 \%$ & $-7.19 \%$ \\
\hline
\end{tabular}

Table 1. Descriptive statistics and VaR for the period 01.01.2000 - 31.12.2017

Source: Authors' processing

Descriptive statistics were calculated in Excel. All data are calculated for the period from 01.01.2000 until 31.12.2017. The same date were used for the calculated parametric VaR. It is important to emphasize that parametric VaR assume normal distribution. During the period from January 2000 to December 2017, the average return on the index of government bonds EG05 was 0.36\%, the Euro Stoxx 50 had a negative return of $0.02 \%$, while gold had the highest return of $0.82 \%$. The standard deviation, as a risk measure, was observed at the highest level with shares at $5.25 \%$, followed by gold at $4.87 \%$. Bonds carry a significantly lower standard deviation; thus, they are considered less risky instruments.

Frequency (Freq) shows the number of observations that are less than 0 , and demonstrates returns that are less than $0 \%$, divided by total observations. This implies that this data shows a return share that is less than $0 \%$ during the analyzed period.

The data show that the lowest returns below $0 \%$ in the analyzed period were recorded in bonds (EG05), where the frequency of negative return has a share of $31.94 \%$, while the largest share of negative returns was recorded in the stock index, where this figure is $46.30 \%$.

$\mathrm{VaR}$ as a risk measure is at the lowest level in bonds, which is further evidence that it is one of the safest instruments of investment.

Descriptive analysis and VaR for the period from January 2007 to December 2017 was calculated in the same way as a previous analysis. The data are presented in Table 2:

\begin{tabular}{cccc}
\hline & EG05 & EURO STOXX50 & Gold \\
\hline Mean & $0.33 \%$ & $0.01 \%$ & $0.69 \%$ \\
\hline StDev & $0.85 \%$ & $5.14 \%$ & $5.33 \%$ \\
\hline Freq<0 & $34.09 \%$ & $46.97 \%$ & $46.21 \%$ \\
\hline Parametric VaR & $-1.07 \%$ & $-8.44 \%$ & $-8.09 \%$ \\
\hline
\end{tabular}

Table 2. Descriptive statistics and VaR for the period 01.01.2007-31.12.2017 
During the crisis period, gold again had the highest average return of $0.69 \%$, while the shares again had the lowest return of $0.01 \%$. Bonds, once more, showed the highest degree of security, considering the data on standard deviation, $\mathrm{VaR}$, and the frequency of negative returns.

For the next step, a return correlation is calculated among the analyzed instruments, as shown in Table 3 :

\begin{tabular}{cccc}
\hline & EG05 & EURO STOXX50 & Gold \\
\hline EG05 & 1 & & \\
\hline EURO STOXX50 & -0.22 & 1 & 1 \\
\hline Gold & 0.08 & -0.09 & \\
\hline
\end{tabular}

Table 3. Correlation for the period 31.01.2000 - 31.12.2017

Source: Authors' processing

Correlation analysis shows almost no correlation amid gold and other financial assets. The difference between the bond index EG05 and gold correlation is only 0.08 , while between the stock index EuroStoxx50 and gold correlation it is slightly negative, at -0.09 .

The correlation between the analyzed data for the crisis and post-crisis period is shown in Table 4:

\begin{tabular}{cccc}
\hline & EG05 & EURO STOXX50 & Gold \\
\hline EG05 & 1 & & \\
\hline EURO STOXX50 & -0.07 & 1 & 1 \\
\hline Gold & 0.09 & -0.09 & \\
\hline
\end{tabular}

Table 4. Correlation for the period 31.01.2007 - 31.12.2017

Source: Authors' processing

In this period, the correlation is almost 0 for all analyzed instruments. Moreover, there is a similar correlation over a longer period of time, as shown in Table 3.

After calculating the correlation, the covariance among the analyzed instruments was taken into consideration. The covariance matrix is shown in Tables 5 and 6 :

\begin{tabular}{cccc}
\hline & EG05 & EURO STOXX50 & Gold \\
\hline EG05 & $0.0078 \%$ & $-0.0093 \%$ & $0.0062 \%$ \\
\hline EURO STOXX50 & $-0.0093 \%$ & $0.2749 \%$ & $-0.0221 \%$ \\
\hline Gold & $0.0062 \%$ & $-0.0221 \%$ & $0.2427 \%$ \\
\hline
\end{tabular}

Table 5. Covariance matrix for the period of 01.01.2000 - 31.12.2017

Source: Authors' processing

\begin{tabular}{cccc}
\hline & EG05 & EURO STOXX50 & Gold \\
\hline EG05 & $0.0083 \%$ & $-0.0029 \%$ & $0.0065 \%$ \\
\hline EURO STOXX50 & $-0.0029 \%$ & $0.2620 \%$ & $-0.0255 \%$ \\
\hline Gold & $0.0065 \%$ & $-0.0255 \%$ & $0.2871 \%$ \\
\hline
\end{tabular}

Table 6: Covariance matrix for the period of 01.01.2007 - 31.12.2017

Source: Authors' processing 
Different portfolios were made using the covariant matrix by taking into consideration the different participation of individual instruments in the portfolio, and with the aim of finding the optimal portfolio using the Markowitz methodology.

An overview of the portfolio offering the minimum standard deviation and the appropriate return for a given level of risk or an effective set is shown in Table 7. When calculating the optimal portfolio, the risk-free rate is fixed at 0\% (German Council of Economic Experts - Annual Report 2016/17). In the current low and negative yield environment in EMU, especially in Germany, which are at the moment negative, up to 7 years.

Table 7 shows data for slope, which represents the slope of the capital market line (CML) and demonstrates the point where CML has a tangency in line with the efficient set. The optimal portfolio is the one with the highest slope. At that point, there is a portfolio that has the lowest standard deviation and the lowest risk, and such is acceptable from the risk-averse investor's perspective.

\begin{tabular}{lcccccccccccccc}
\hline Return & $0.25 \%$ & $0.30 \%$ & $0.35 \%$ & $0.39 \%$ & $0.40 \%$ & $0.45 \%$ & $0.50 \%$ & $0.55 \%$ & $0.60 \%$ & $0.65 \%$ & $0.70 \%$ & $0.75 \%$ & $0.80 \%$ \\
\hline Risk & $1.53 \%$ & $1.00 \%$ & $0.83 \%$ & $2.3 \%$ & $0.97 \%$ & $1.28 \%$ & $1.71 \%$ & $2.18 \%$ & $2.67 \%$ & $3.18 \%$ & $3.69 \%$ & $4.21 \%$ & $4.73 \%$ \\
\hline Slope & 0.1634 & 0.3012 & 0.4140 & 0.17 & 0.4125 & 0.3506 & 0.2928 & 0.2524 & 0.2245 & 0.2045 & 0.1197 & 0.1782 & 0.1692 \\
\hline EG05 & $70.86 \%$ & $84.21 \%$ & $93.31 \%$ & $33.33 \%$ & $90.18 \%$ & $80.24 \%$ & $69.37 \%$ & $58.50 \%$ & $47.62 \%$ & $36.75 \%$ & $25.88 \%$ & $15.01 \%$ & $4.14 \%$ \\
\hline $\begin{array}{l}\text { EURO } \\
\text { STOXX50 }\end{array}$ & $29.14 \%$ & $15.79 \%$ & $5.73 \%$ & $33.33 \%$ & $0.51 \%$ & $0.00 \%$ & $0.00 \%$ & $0.00 \%$ & $0.00 \%$ & $0.00 \%$ & $0.00 \%$ & $0.00 \%$ & $0.00 \%$ \\
\hline Gold & $0.00 \%$ & $0.0 \%$ & $0.96 \%$ & $33.34 \%$ & $9.30 \%$ & $19.76 \%$ & $30.63 \%$ & $41.50 \%$ & $52.38 \%$ & $63.25 \%$ & $74.12 \%$ & $84.99 \%$ & $95.86 \%$ \\
\hline
\end{tabular}

Table 7. An overview of different portfolios, and optimal portfolio for a period of 01.01.2000-31.12.2017 Source: Authors' processing in Excel

All the calculations are made in Excel, using the Solver function. At the first step it was calculated portfolio who has the lowest standard deviation or the lowest risk.

For the second step, we chose a different rate of the returns, between $0.2 \%$ up to $0.8 \%$, which was the maximum returns that gold had during the analyzed period (from 01.01.2000 until 31.12.2017). We therefore used returns from $0.250 \%$ and increased it up to a 5 basis point, as shown in Table 7 . When determining the target return, we used Solver function to find the instrument share that offer desirable return. The average portfolio return was calculated considering the average returns of each instrument and their share in portfolios compared with the risk-free rate, which was set to $0 \%$. The slope was calculated just as a ratio between portfolio return and portfolio risk. As we can see, we calculated a different returns rate, and show a share of each instrument in corresponding returns. We also calculated returns and risk in case that portfolio consist the same share of each instrument. In that case portfolio has a returns of $0.357 \%$ but the risk of this portfolio is $2.3 \%$ which is quite high. The same level of return investor can have with a lower risk, as it is shown in Table 7.

The results demonstrate that, from the standpoint of the risk-averse investor, the acceptable portfolio is one that offers an expected return of $0.3 \%$ with a standard deviation of $0.80 \%$, which is represented by the tangent of the efficient set line, as shown in Figure 1: 


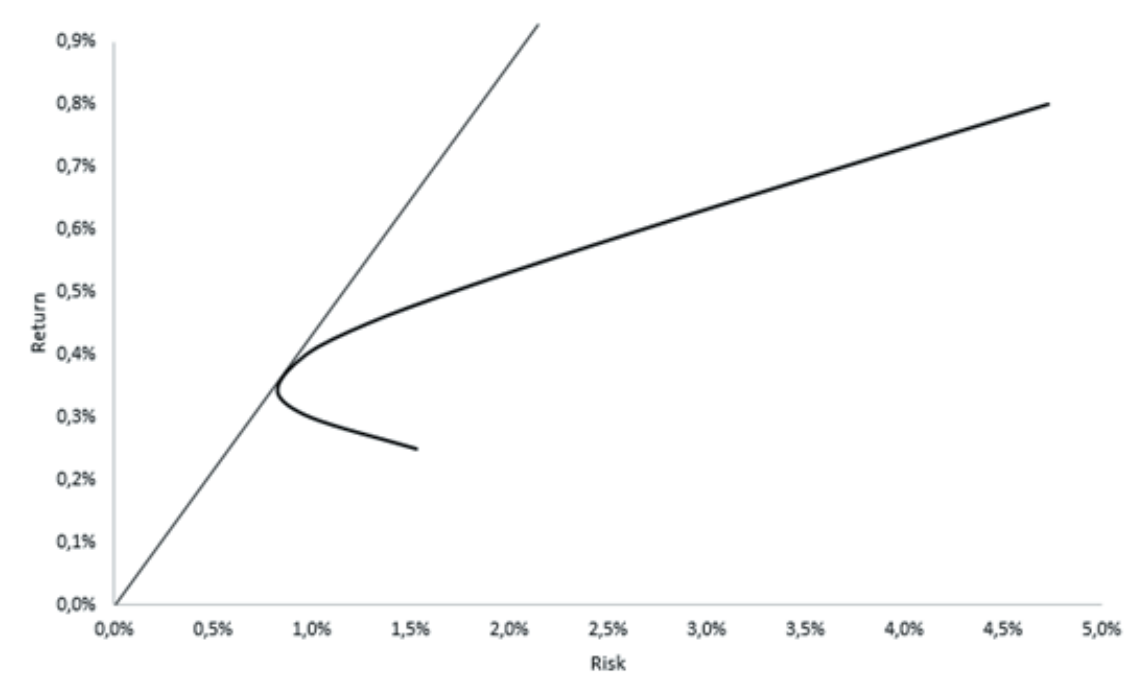

Figure 1. Efficient set for a period of 01.01.2000 - 31.12.2017

Source: Authors' processing

If an investor is risk averse, then the optimal portfolio should contain $93.3 \%$ of bonds, $5.7 \%$ shares, and the share of gold should be $1 \%$. On the other hand, the portfolio with an expected return of $0.4 \%$ and a standard deviation of $1 \%$ can be considered an optimal portfolio. It is a portfolio made up with $90.2 \%$ of bonds, $0.5 \%$ of shares and $9.3 \%$ gold. This portfolio has a higher expected return, but also a slightly higher risk.

However, the structure of the portfolio that the investor will adopt depending on investor's risk appetite. This means that a portfolio that includes $9.3 \%$ of gold could be considered as optimal. Likewise, if an investor is ready to take on more risk, the possibility exists of including a larger share of gold in the investment portfolio.

The following phase included testing of an optimal portfolio using the same instruments for the period during the global crisis and beyond, from January 2007 to December 2017. The same calculations were used in this case. The efficient set is given in Table 8 and Figure 2:

\begin{tabular}{lcccccccccccccc}
\hline Return & $\mathbf{0 . 1 5} \%$ & $\mathbf{0 . 2 0} \%$ & $\mathbf{0 . 2 5} \%$ & $\mathbf{0 . 3 2} \%$ & $\mathbf{0 . 3 4} \%$ & $\mathbf{0 . 3 5} \%$ & $\mathbf{0 . 4 0} \%$ & $\mathbf{0 . 4 5} \%$ & $\mathbf{0 . 5 0} \%$ & $\mathbf{0 . 5 5} \%$ & $\mathbf{0 . 6 0} \%$ & $\mathbf{0 . 6 5} \%$ & $\mathbf{0 . 6 8} \%$ \\
\hline Risk & $\mathbf{2 . 8 6} \%$ & $\mathbf{2 . 0 9} \%$ & $\mathbf{1 . 3 8} \%$ & $\mathbf{0 . 8 8} \%$ & $\mathbf{2 . 3 9} \%$ & $\mathbf{0 . 9 6} \%$ & $\mathbf{1 . 3 9} \%$ & $\mathbf{2 . 0 1} \%$ & $\mathbf{2 . 6 8} \%$ & $\mathbf{3 . 3 9} \%$ & $\mathbf{4 . 1 0} \%$ & $\mathbf{4 . 8 2} \%$ & $\mathbf{5 . 2 6} \%$ \\
\hline Slope & $\mathbf{0 . 0 5 2 4}$ & $\mathbf{0 . 0 9 5 7}$ & $\mathbf{0 . 1 8 1 0}$ & $\mathbf{0 . 3 5 9 0}$ & $\mathbf{0 . 1 4}$ & $\mathbf{0 . 3 6 4 3}$ & $\mathbf{0 . 2 8 8 0}$ & $\mathbf{0 . 2 2 4 4}$ & $\mathbf{0 . 1 8 6 3}$ & $\mathbf{0 . 1 6 2 4}$ & $\mathbf{0 . 1 4 6 2}$ & $\mathbf{0 . 1 3 4 7}$ & $\mathbf{0 . 1 2 9 3}$ \\
\hline EG05 & $44.11 \%$ & $59.94 \%$ & $75.77 \%$ & $94.96 \%$ & $33.33 \%$ & $93.51 \%$ & $79.60 \%$ & $65.72 \%$ & $51.84 \%$ & $37.96 \%$ & $24.08 \%$ & $10.20 \%$ & $1.87 \%$ \\
\hline $\begin{array}{l}\text { EURO } \\
\text { STOXX50 }\end{array}$ & $55.89 \%$ & $40.06 \%$ & $24.23 \%$ & $4.11 \%$ & $33.33 \%$ & $0.00 \%$ & $0.00 \%$ & $0.00 \%$ & $0.00 \%$ & $0.00 \%$ & $0.00 \%$ & $0.00 \%$ & $0.00 \%$ \\
\hline Gold & $0.00 \%$ & $0.00 \%$ & $0.00 \%$ & $0.93 \%$ & $33.34 \%$ & $6.49 \%$ & $20.40 \%$ & $34.28 \%$ & $48.16 \%$ & $62.04 \%$ & $75.92 \%$ & $89.80 \%$ & $98.13 \%$ \\
\hline
\end{tabular}

Table 8. Overview of different portfolios and optimal portfolio for a period of 01.01.2007 - 31.12.2017 Source: Authors' processing 
Efficient set is shown in Figure 2:

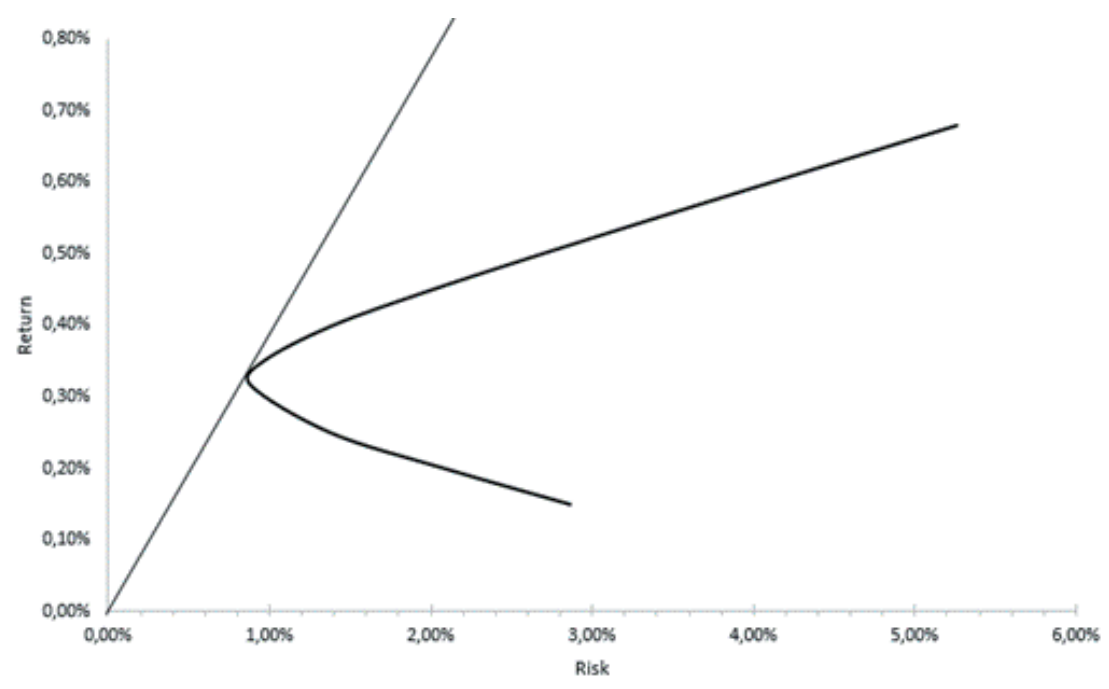

Figure 2. Efficient set for a period of 01.01.2007 - 31.12.2017

Source: Authors' processing

An optimal portfolio comprises $93.5 \%$ of bonds, $6.5 \%$ of gold, and no stock. This portfolio has an expected return of $0.35 \%$ and a risk of $0.96 \%$. If the investor favours a somewhat lower risk, the portfolio can consist of $95 \%$ of bonds, $4.1 \%$ of shares and $0.9 \%$ of gold. These findings confirm that, during the crisis, it was optimal to include gold in portfolios.

\section{CONCLUSION}

Economic crises, turbulence, and uncertainties in financial markets emphasize the importance of risk management strategies and portfolio diversification. At the same time, it is evident that the correlation between traditional assets, shares, and bonds is increasing. If these circumstances are considered in combination with poor returns offered by the stock, it can be concluded that investors are more interested in pursuing other investment assets, such as monetary gold.

Previous research has indicated that investors have different attitudes towards the role of gold in the portfolio. Some advocate its inclusion in portfolios, while others consider it is not beneficial. Decisions to include monetary gold in the portfolio will ultimately depend on the investor, investment objectives, and the interest in portfolio diversification.

The purpose of this study was to examine whether gold has an important role in investment portfolios from the perspective of European investors that invest in traditional assets, stocks, and bonds. Three instruments were combined - bonds, stocks and gold, whereas the optimal portfolio was found by Markowitz portfolio theory. The analyzed period was from January 2000 to December 2017, while the observation period was segmented into two periods covering the entire analyzed period, from January 2000 to December 2017, and the period of global crisis and the post-crisis period, from January 2007 to December 2017. This study tested the hypothesis that gold represents a useful instrument for portfolio diversification and, as such, is a desirable instrument in investment portfolios. 
Following the research results, it can be concluded that gold represents an important instrument for portfolio diversification and, therefore, shares between $1 \%$ and $9 \%$ are recommended for inclusion in portfolios. It can also be argued that it is justifiable to include gold in investment portfolios if the portfolio is combined with European bonds and stocks. Gold is a good basis for diversification portfolios, both from the standpoint of the risk-averse investor and from the aspect of the investor prepared to take a higher risk.

\section{REFERENCES}

Baur, D., \& Lucey, B. (2010). Is gold a hedge or a safe haven? An analysis of stocks, bonds and gold. Financial Review, 45(2), 217-229.

Bernhart, G., Höcht, S., Neugebauer, M., Neumann, M., \& Zagst, R. (2011). Asset correlations in turbulent markets and the impact of different regimes on asset management. Asia-Pacific Journal of Operational Research, 28(1), 1-23. DOI:10.1142/S0217595911003028

Bodie, Z., Kane, A., Marcus, A. (2014). Investment. New York: McGraw-Hill Education.

Capie, F., Mills, T. C., \& Wood, G. (2005). Gold as a hedge against the dollar. Journal of International Financial Markets Institutions and Money, 15(4), 343-352.

Clapperton, G. (2010). Raising the gold standard. Engineering \& Technology, 5(15), 66-69. DOI:10.1049/et.2010.1514

Conover, C. M., Jensen, G. R., Johnson, R. R., \& Mercer, J. M. (2009). Can precious metals make your portfolio shine? Journal of Investing, 18(1), 75-86. DOI:10.3905/JOI.2009.18.1.075

Conover, C. M., Jensen, G. R., Johnson, R. R., \& Mercer, J. M. (2010). Is now the time to add commodities to your portfolio? The Journal of Investing, 19(3), 10-19. DOI:10.3905/joi.2010.19.3.010

Daskalaki, C., \& Skiadopoulos, G. (2011). Should investors include commodities in their portfolios after all? New evidence. Journal of Banking and Finance, 35(10), 2606-2626. DOI:10.1016/j.jbankfin.2011.02.02

Erb, C. B., \& Harvey, C. R. (2013). The Golden Dilemma. Financial Analysts Journal, 69(4), 10-42. DOI:10.2139/ ssrn. 2078535

Fernandno, N. (2017). The Role of Gold in an Investment Portfolio: An empirical study on diversification benefits of gold from the perspective of Swedish investors. Umeå: University

German Council of Economic Experts.

Ghosh, D., Levin, E. J., Macmillan, P., \& Wright, R. E. (2004). Gold as an inflation hedge. Studies in Economics and Finance, 22, 1-25.

Hillier, D., Draper, P., \& Faff, R. (2006). Do precious metals shine? An investment perspective. Financial Analysts Journal, 62(2), 98-106. DOI:10.2469/faj.v62.n2.4085

Idzorek, T. M. (2005). Portfolio diversification with Gold, Silver, and Platinum. Chicago: Ibbotson Associates.

Idzorek, T. M. (2006). Strategic asset allocation and commodities. Chicago: Ibbotson Associates.

Johnson, R., \& Soenen, L. (1997). Gold as an investment asset: Perspectives from different countries. Journal of Investing, 6(3), 91-99. DOI: 10.3905/joi.1997.408427

Joy, M. (2011). Gold and the US dollar: hedge or haven? Finance Research Letters, 8(3), 120-131. DOI:10.1016/j. frl.2011.01.001

Levišauskait, K. (2010). Investment Analysis and Portfolio Management. Lithuania: Vytautas Magnus University Kaunas.

Lucey, B., Poti,V., Tully, E. (2006). International Portfolio Formation, Skewness and the Role of Gold. DOI:10.2139/ ssrn. 452482

Merk Investments, LLC. (2012). The Case for Gold: Portfolio Benefits of the Ultimate Currency. Retrieved October 28, 2018, from https://www.merkinvestments.com/gold/white-papers/downloadcaseforgold-portfoliobenefits.php 
Michaud, R., Michaud, R., Ecsh, D., Schroeder, E. (2011). Gold as strategic assets for European investor. New York: World Gold Council.

Pullen, T., Bensen, K., \& Faff, R. (2014). A comparative analysis of the investment characteristics of alternative gold assets. Abacus, 50(1), 76-92. DOI:10.2139/ssrn.1928591

Ratner, M., \& Klein, S. (2008). The portfolio implications of gold investment. The Journal of Investing, 17(1), 77-87. DOI:10.3905/joi.2008.701958

Sherman, E. (1982). Gold: A Conservative, Prudent Diversifier. Journal of Portfolio Management, 8(3), 21-27. DOI:10.3905/jpm.1982.408850

World Gold Council. (2018). Investment Update: IMF report highlights gold's relevance. Retrieved October 28, 2018, from https://www.gold.org/goldhub/research/imf-report-highlights-golds-relevance 


\section{APPENDIX}

\begin{tabular}{|c|c|c|c|}
\hline Date & EG05 & EURO STOXX50 & Gold (in USD) \\
\hline 31.12 .2017 & 638.241 & 3503.96 & 1302.8 \\
\hline 30.11 .2017 & 641.495 & 3569.93 & 1271.72 \\
\hline 31.10 .2017 & 640.889 & 3673.95 & 1270.34 \\
\hline 29.9.2017 & 637.124 & 3594.85 & 1279.75 \\
\hline 31.8.2017 & 638.318 & 3421.47 & 1316.96 \\
\hline 31.7.2017 & 635.338 & 3449.36 & 1267.9 \\
\hline 30.6 .2017 & 633.954 & 3441.88 & 1241.61 \\
\hline 31.5.2017 & 636.571 & 3554.59 & 1269.86 \\
\hline 28.4.2017 & 633.943 & 3559.59 & 1268.28 \\
\hline 31.3.2017 & 631.627 & 3500.93 & 1249.2 \\
\hline 28.2.2017 & 633.707 & 3319.61 & 1256.37 \\
\hline 31.1.2017 & 629.714 & 3230.68 & 1210.59 \\
\hline 30.12 .2016 & 636.44 & 3290.52 & 1147.5 \\
\hline 30.11 .2016 & 632.685 & 3051.61 & 1174.94 \\
\hline 31.10 .2016 & 637.026 & 3055.25 & 1273.76 \\
\hline 30.9.2016 & 643.661 & 3002.24 & 1315.87 \\
\hline 31.8 .2016 & 642.57 & 3023.13 & 1308.17 \\
\hline 29.7.2016 & 642.626 & 2990.76 & 1351.28 \\
\hline 30.6 .2016 & 640.275 & 2864.74 & 1316.13 \\
\hline 31.5 .2016 & 635.125 & 3063.48 & 1214.88 \\
\hline 29.4.2016 & 631.786 & 3028.21 & 1293.53 \\
\hline 31.3.2016 & 634.553 & 3004.93 & 1232.44 \\
\hline 29.2.2016 & 633.492 & 2945.75 & 1232.07 \\
\hline 29.1.2016 & 630.91 & 3045.09 & 1118.21 \\
\hline 31.12 .2015 & 624.272 & 3267.52 & 1062.19 \\
\hline 30.11 .2015 & 627.997 & 3506.45 & 1064.17 \\
\hline 30.10 .2015 & 624.822 & 3418.23 & 1142.11 \\
\hline 30.9 .2015 & 620.819 & 3100.67 & 1114.9 \\
\hline 31.8 .2015 & 616.142 & 3269.63 & 1133.72 \\
\hline 31.7.2015 & 619.113 & 3600.69 & 1095.8 \\
\hline 30.6 .2015 & 611.707 & 3424.3 & 1173.76 \\
\hline 29.5.2015 & 618.451 & 3570.78 & 1190.58 \\
\hline 30.4 .2015 & 621.706 & 3615.59 & 1181.44 \\
\hline 31.3 .2015 & 624.871 & 3697.38 & 1183.88 \\
\hline 27.2.2015 & 623.269 & 3599 & 1213.18 \\
\hline 30.1 .2015 & 619.8 & 3351.44 & 1283.79 \\
\hline 31.12 .2014 & 615.374 & 3146.43 & 1187.96 \\
\hline
\end{tabular}




\begin{tabular}{|c|c|c|c|}
\hline 28.11.2014 & 612.503 & 3250.93 & 1167.38 \\
\hline 31.10 .2014 & 608.391 & 3113.32 & 1172.94 \\
\hline 30.9 .2014 & 608.153 & 3225.93 & 1208.67 \\
\hline 29.8.2014 & 606.714 & 3172.63 & 1287.32 \\
\hline 31.7.2014 & 600.64 & 3115.51 & 1282.28 \\
\hline 30.6 .2014 & 597.679 & 3228.24 & 1318.35 \\
\hline 30.5 .2014 & 592.667 & 3244.6 & 1249.68 \\
\hline 30.4 .2014 & 588.373 & 3198.39 & 1293.5 \\
\hline 31.3.2014 & 585.007 & 3161.6 & 1286.92 \\
\hline 28.2.2014 & 581.198 & 3149.23 & 1326.39 \\
\hline 31.1.2014 & 578.525 & 3013.96 & 1244.55 \\
\hline 31.12 .2013 & 569.519 & 3109 & 1204.99 \\
\hline 29.11 .2013 & 572.521 & 3086.64 & 1253.35 \\
\hline 31.10 .2013 & 570.194 & 3067.95 & 1323.66 \\
\hline 30.9 .2013 & 563.645 & 2893.15 & 1331.77 \\
\hline 30.8 .2013 & 560.243 & 2721.37 & 1395.27 \\
\hline 31.7.2013 & 561.747 & 2768.15 & 1308.29 \\
\hline 28.6.2013 & 557.649 & 2602.59 & 1234.53 \\
\hline 31.5.2013 & 563.957 & 2769.64 & 1387.8 \\
\hline 30.4 .2013 & 568.492 & 2712 & 1471.96 \\
\hline 29.3.2013 & 558.774 & 2624.02 & 1597.5 \\
\hline 28.2.2013 & 556.154 & 2633.55 & 1581.4 \\
\hline 31.1 .2013 & 553.812 & 2702.98 & 1662.51 \\
\hline 31.12 .2012 & 555.636 & 2635.93 & 1676.23 \\
\hline 30.11 .2012 & 553.361 & 2575.25 & 1714.98 \\
\hline 31.10 .2012 & 547.385 & 2503.64 & 1719.35 \\
\hline 28.9.2012 & 543.972 & 2454.26 & 1772.25 \\
\hline 31.8.2012 & 537.781 & 2440.71 & 1691.85 \\
\hline 31.7 .2012 & 533.277 & 2325.72 & 1615.73 \\
\hline 29.6.2012 & 527.468 & 2264.72 & 1597.45 \\
\hline 31.5.2012 & 527.342 & 2118.94 & 1566.84 \\
\hline 30.4 .2012 & 526.463 & 2306.43 & 1663.81 \\
\hline 30.3 .2012 & 526.888 & 2477.28 & 1668.15 \\
\hline 29.2.2012 & 526.85 & 2512.11 & 1721.9 \\
\hline 31.1 .2012 & 519.543 & 2416.66 & 1730.91 \\
\hline 30.12 .2011 & 509.712 & 2316.55 & 1564.91 \\
\hline 30.11 .2011 & 493.849 & 2330.43 & 1745.59 \\
\hline 31.10 .2011 & 504.583 & 2385.22 & 1724.48 \\
\hline 30.9 .2011 & 511.382 & 2179.66 & 1623.79 \\
\hline 31.8.2011 & 509.716 & 2302.08 & 1834.99 \\
\hline
\end{tabular}




\begin{tabular}{|c|c|c|c|}
\hline 29.7.2011 & 495.494 & 2670.37 & 1627.05 \\
\hline 30.6 .2011 & 495.81 & 2848.53 & 1504.72 \\
\hline 31.5.2011 & 496.187 & 2861.92 & 1536.23 \\
\hline 29.4.2011 & 492.119 & 3011.25 & 1563.7 \\
\hline 31.3.2011 & 490.879 & 2910.91 & 1437.78 \\
\hline 28.2.2011 & 493.412 & 3013.09 & 1411.88 \\
\hline 31.1 .2011 & 492.856 & 2953.63 & 1337.14 \\
\hline 31.12 .2010 & 494.774 & 2792.82 & 1421.4 \\
\hline 30.11 .2010 & 494.947 & 2650.99 & 1388.53 \\
\hline 29.10 .2010 & 504.495 & 2844.99 & 1359.4 \\
\hline 30.9 .2010 & 505.976 & 2747.9 & 1307.6 \\
\hline 31.8 .2010 & 509.88 & 2622.95 & 1248.45 \\
\hline 30.7 .2010 & 503.02 & 2742.14 & 1181 \\
\hline 30.6 .2010 & 499.319 & 2573.32 & 1241.68 \\
\hline 31.5.2010 & 502.363 & 2610.26 & 1216,45 \\
\hline 30.4 .2010 & 495.374 & 2816.86 & 1179.03 \\
\hline 31.3.2010 & 499.629 & 2931.16 & 1114.49 \\
\hline 26.2 .2010 & 496.943 & 2728.47 & 1117.59 \\
\hline 29.1.2010 & 491.722 & 2776.3 & 1081.2 \\
\hline 31.12 .2009 & 490.316 & 2964.96 & 1098.65 \\
\hline 30.11 .2009 & 493.412 & 2797.25 & 1173.38 \\
\hline 30.10 .2009 & 491.131 & 2743.5 & 1045.45 \\
\hline 30.9.2009 & 489.72 & 2872.63 & 1007.6 \\
\hline 31.8.2009 & 487.214 & 2775.17 & 950.94 \\
\hline 31.7.2009 & 485.857 & 2638.13 & 954 \\
\hline 30.6 .2009 & 480.278 & 2401.69 & 930 \\
\hline 29.5.2009 & 475.594 & 2451.24 & 975.75 \\
\hline 30.4 .2009 & 477.869 & 2375.34 & 887.95 \\
\hline 31.3.2009 & 476.288 & 2071.13 & 919.9 \\
\hline 27.2.2009 & 471.51 & 1976.23 & 942.32 \\
\hline 30.1 .2009 & 466.974 & 2236.98 & 927.85 \\
\hline 31.12 .2008 & 467.308 & 2447.62 & 875.43 \\
\hline 28.11 .2008 & 462.422 & 2430.31 & 817.68 \\
\hline 31.10 .2008 & 451.291 & 2591.76 & 721.8 \\
\hline 30.9.2008 & 445.312 & 3038.2 & 875.55 \\
\hline 29.8.2008 & 441.124 & 3365.63 & 831.86 \\
\hline 31.7.2008 & 436.608 & 3367.82 & 917.43 \\
\hline 30.6 .2008 & 429.084 & 3352.81 & 923.56 \\
\hline 30.5 .2008 & 433.308 & 3777.85 & 885.43 \\
\hline 30.4 .2008 & 437.87 & 3825.02 & 867.03 \\
\hline
\end{tabular}




\begin{tabular}{|c|c|c|c|}
\hline 31.3.2008 & 440.356 & 3628.06 & 920.96 \\
\hline 29.2.2008 & 443.148 & 3724.5 & 973.08 \\
\hline 31.1.2008 & 439.559 & 3792.8 & 924.49 \\
\hline 31.12 .2007 & 430.095 & 4399.72 & 833.05 \\
\hline 30.11 .2007 & 431.422 & 4394.95 & 782.92 \\
\hline 31.10 .2007 & 427.392 & 4489.79 & 790.5 \\
\hline 28.9.2007 & 425.132 & 4381.71 & 743.75 \\
\hline 31.8.2007 & 424.446 & 4294.56 & 673 \\
\hline 31.7.2007 & 419.959 & 4315.69 & 665.15 \\
\hline 29.6.2007 & 415.629 & 4489.77 & 650.9 \\
\hline 31.5 .2007 & 416.385 & 4512.65 & 659.45 \\
\hline 30.4 .2007 & 419.29 & 4392.34 & 680.85 \\
\hline 30.3.2007 & 419.548 & 4181.03 & 665.05 \\
\hline 28.2.2007 & 420.04 & 4087.12 & 667.89 \\
\hline 31.1.2007 & 416.732 & 4178.54 & 650.53 \\
\hline 29.12 .2006 & 417.009 & 4119.94 & 635.7 \\
\hline 30.11 .2006 & 420.368 & 3987.23 & 647.5 \\
\hline 31.10 .2006 & 418.359 & 4004.8 & 604.8 \\
\hline 29.9.2006 & 417.856 & 3899.41 & 596.55 \\
\hline 31.8.2006 & 416.63 & 3808.7 & 626.28 \\
\hline 31.7 .2006 & 413.59 & 3691.87 & 633.36 \\
\hline 30.6 .2006 & 410.221 & 3648.92 & 613.99 \\
\hline 31.5 .2006 & 411.224 & 3637.17 & 642 \\
\hline 28.4.2006 & 409.208 & 3839.9 & 653.23 \\
\hline 31.3.2006 & 410.779 & 3853.74 & 582.85 \\
\hline 28.2.2006 & 414.24 & 3774.51 & 561.2 \\
\hline 31.1.2006 & 413.913 & 3691.41 & 571.95 \\
\hline 30.12 .2005 & 415.407 & 3578.93 & 517 \\
\hline 30.11 .2005 & 413.302 & 3447.07 & 494.7 \\
\hline 31.10 .2005 & 413.777 & 3320.15 & 467.4 \\
\hline 30.9 .2005 & 416.944 & 3428.51 & 469 \\
\hline 31.8 .2005 & 417.7 & 3263.78 & 434.53 \\
\hline 29.7.2005 & 414.953 & 3326.51 & 430.55 \\
\hline 30.6.2005 & 416.616 & 3181.54 & 435.88 \\
\hline 31.5 .2005 & 413.095 & 3076.7 & 417.1 \\
\hline 29.4.2005 & 409.742 & 2930.1 & 436.01 \\
\hline 31.3 .2005 & 404.74 & 3055.73 & 428.24 \\
\hline 28.2.2005 & 402.807 & 3058.32 & 436 \\
\hline 31.1 .2005 & 404.033 & 2984.59 & 421.5 \\
\hline 31.12 .2004 & 401.059 & 2951.01 & 438.05 \\
\hline
\end{tabular}




\begin{tabular}{|c|c|c|c|}
\hline 30.11 .2004 & 399.46 & 2876.39 & 450.65 \\
\hline 29.10 .2004 & 396.423 & 2811.72 & 427.04 \\
\hline 30.9.2004 & 393.015 & 2726.3 & 418.1 \\
\hline 31.8.2004 & 391.957 & 2670.79 & 409.7 \\
\hline 30.7 .2004 & 387.505 & 2720.05 & 390.2 \\
\hline 30.6 .2004 & 384.768 & 2811.08 & 394 \\
\hline 31.5.2004 & 384.321 & 2749.62 & 395.35 \\
\hline 30.4 .2004 & 384.74 & 2787.48 & 389.3 \\
\hline 31.3.2004 & 388.056 & 2787.49 & 425.1 \\
\hline 27.2.2004 & 384.969 & 2893.18 & 397 \\
\hline 30.1.2004 & 379.994 & 2839.13 & 401.2 \\
\hline 31.12 .2003 & 377.864 & 2760.66 & 415.05 \\
\hline 28.11.2003 & 373.375 & 2630.47 & 397.75 \\
\hline 31.10 .2003 & 374.508 & 2575.04 & 383.05 \\
\hline 30.9 .2003 & 379.013 & 2395.87 & 387.28 \\
\hline 29.8.2003 & 373.316 & 2556.71 & 375.55 \\
\hline 31.7.2003 & 373.502 & 2519.79 & 355.95 \\
\hline 30.6 .2003 & 378.124 & 2419.51 & 346.35 \\
\hline 30.5 .2003 & 377.63 & 2330.06 & 364.55 \\
\hline 30.4 .2003 & 371.016 & 2324.23 & 339.15 \\
\hline 31.3.2003 & 370.291 & 2036.86 & 335.95 \\
\hline 28.2.2003 & 371.142 & 2140.73 & 349.75 \\
\hline 31.1 .2003 & 366.924 & 2248.17 & 368.05 \\
\hline 31.12 .2002 & 363.57 & 2398.65 & 347.85 \\
\hline 29.11.2002 & 357.251 & 2656.85 & 318.95 \\
\hline 31.10 .2002 & 355.617 & 2518.99 & 317.55 \\
\hline 30.9.2002 & 356.676 & 2204.39 & 324.05 \\
\hline 30.8 .2002 & 350.043 & 2709.29 & 312.75 \\
\hline 31.7.2002 & 346.321 & 2685.79 & 302.43 \\
\hline 28.6.2002 & 341.548 & 3133.39 & 317.25 \\
\hline 31.5.2002 & 336.716 & 3425.79 & 325.25 \\
\hline 30.4 .2002 & 336.189 & 3574.23 & 308.15 \\
\hline 29.3.2002 & 332.727 & 3784.05 & 302.5 \\
\hline 28.2.2002 & 335.481 & 3624.74 & 296.65 \\
\hline 31.1 .2002 & 334.303 & 3670.26 & 281.85 \\
\hline 31.12 .2001 & 333.723 & 3806.13 & 278.95 \\
\hline 30.11 .2001 & 337.01 & 3658.27 & 275.05 \\
\hline 31.10 .2001 & 338.616 & 3478.63 & 279.85 \\
\hline 28.9.2001 & 332.602 & 3296.66 & 292.55 \\
\hline 31.8 .2001 & 329.468 & 3743.97 & 274.45 \\
\hline
\end{tabular}




\begin{tabular}{|c|c|c|c|}
\hline 31.7.2001 & 326.218 & 4091.38 & 266.15 \\
\hline 29.6.2001 & 322.34 & 4243.91 & 271.55 \\
\hline 31.5.2001 & 319.845 & 4426.24 & 266.6 \\
\hline 30.4 .2001 & 318.476 & 4525.01 & 263.48 \\
\hline 30.3 .2001 & 321.816 & 4185 & 257.95 \\
\hline 28.2.2001 & 319.136 & 4318.88 & 267.15 \\
\hline 31.1 .2001 & 317.688 & 4779.9 & 265.2 \\
\hline 29.12.2000 & 315.543 & 4772.39 & 272.25 \\
\hline 30.11 .2000 & 311.145 & 4790.08 & 269 \\
\hline 31.10 .2000 & 307.107 & 5057.46 & 264.68 \\
\hline 29.9.2000 & 305.635 & 4915.18 & 274.25 \\
\hline 31.8.2000 & 302.854 & 5175.12 & 277.25 \\
\hline 31.7 .2000 & 302.772 & 5122.8 & 277.25 \\
\hline 30.6 .2000 & 302.037 & 5145.35 & 289.15 \\
\hline 31.5 .2000 & 300.393 & 5200.89 & 272.6 \\
\hline 28.4.2000 & 300.332 & 5303.95 & 274.5 \\
\hline 31.3 .2000 & 300.485 & 5249.55 & 279.73 \\
\hline 29.2.2000 & 296.822 & 5182.62 & 293.3 \\
\hline 31.1 .2000 & 295.425 & 4684.48 & 283.6 \\
\hline 31.12.1999 & 296.306 & 4904.46 & 288 \\
\hline
\end{tabular}

Table 9. Raw data, monthly values for all variables

Source: Bloomberg

\section{ZLATO U PORTFOLIO INVESTICIJAMA IZ UGLA EVROPSKOG ULAGAČA}

\section{Rezime:}

Zlato je jedinstven vid imovine, velike vrednosti, ali, u isto vreme, vid kojeg nema dovoljno na raspolaganju. U pitanju je imovina luksuzne prirode, koja se može smatrati sjajnom prilikom za ulaganje. Takođe, zlato je imovina koja ne nosi rizik druge strane - odnosno, ne uključuje povezani kreditni rizik. Upravo zbog ovih osobina, zlato predstavlja značajan oblik imovine i ima izuzetno važnu ulogu u portfolio investicijama. Navedene okolnosti uvećavaju interese ulagača da uvrste zlato u portfolio investicije, posebno tokom perioda finansijskih kriza. Ukoliko ulagač odluči da to učini, neophodno je proceniti udeo zlata u portfoliju, uzimajući u obzir apskte rizika, povraćaja i diversifikacije. U ovom radu, testirana je, i potvrđena hipoteza na osnovu koje zlato omogućava diversifikaciju za portfolio investicije, što implicira da je zlato poželjan oblik imovine u ovom kontekstu. Istraživanje se fokusiralo na razvoj optimalnog portfolija, koji kombinuje indeks obveznica Evrozone sa investicionim rejtingom 1-10 godina (EG 05), indeks Euro Stoxx 50 i zlato, uz upotrebu metodologije autora Markowitz. Rezultati su pokazali da optimalan portfolio treba da uključuje zlato sa udelom 1-9\%, u zavisnosti od rizika koji je ulagač spreman da prihvati.

\section{Ključne reči:}

zlato, investicije, portfolio, kriza. 